\title{
PEPSIN-CELLULASE DIGESTIBILITY OF PASTURE SILAGES: EFFECTS OF PASTURE TYPE, MATURITY STAGE, AND VARIATIONS IN THE ENZYMATIC METHOD
}

\author{
Claudia Barchiesi-Ferrari' ${ }^{1}$, Daniel Alomar ${ }^{2 *}$, and Horacio Miranda ${ }^{1}$
}

\begin{abstract}
Enzymatic in vitro digestibility has been studied as a method to predict energy values of forages for ruminants, although results have been affected by type of forage and methodological details of the technique. This work was performed to evaluate the effects of cellulase concentration $\left(0.75,1.0\right.$ and $\left.6.25 \mathrm{~g} \mathrm{~L}^{-1}\right)$, incubation time $(24 \mathrm{or} 48 \mathrm{~h})$ and type of final washing of the residue (water or acetone) on the in vitro digestibility of the dry matter (DMD), organic matter (OMD) and content of digestible organic matter in the DM (D value) of silages made at three maturity stages from three types of pastures: a) permanent pasture (Dactylis glomerata, Lolium perenne, Bromus catharticus Vahl var. catharticus, Trifolium repens and Holcus lanatus); b) Italian ryegrass ley (Lolium multiflorum Lam. cv. Tama); c) oats (Avena sativa L.) and d) mixed pasture (L. perenne-T. repens). Regression equations among cellulase results and in vitro values obtained with rumen fluid were also developed. Higher enzyme concentration, longer incubation time and final washing with acetone, resulted in a significant $(\mathrm{P}<0.05)$ increase in $\mathrm{DMD}$, OMD and $\mathrm{D}$ value. A strong interaction $(\mathrm{P}<0.001)$ among forage type, maturity stage and incubation time was observed. Interactions between stage and enzyme concentration were also apparent $(\mathrm{P}<0.05)$ for $\mathrm{D}$ value, DMD and OMD. Type of pasture and maturity affected the performance of the enzymatic method to predict in vitro digestibility obtained with rumen fluid. Therefore, different prediction equations should be developed for any combination of the above mentioned factors. Adjusting this methodology with in vivo data is encouraged to improve prediction of digestibility values.
\end{abstract}

Key words: Cellulase incubation, enzymatic digestibility, in vitro digestibility.

$\mathrm{P}$ asture silage is an important component of the winter diet of dairy cows in humid, temperate zones, as southern Chile. In those management conditions, the herd productivity relies heavily on the quality of the silage produced, determined either in terms of its composition, digestibility or fermentation characteristics (Huhtanen et al., 2005). Therefore, it is important that reliable methods are available to determine or predict silage composition and quality traits, such as digestibility of the dry matter (DMD), digestibility of the organic matter (OMD) and the content of digestible organic matter in the dry matter (DOMD or D value) in order to assist to the formulation of balanced rations for ruminants (Beever and Mould, 2000). In particular, DMD and D value are important traits to estimate, given the relationship these variables present

${ }^{1}$ Universidad de La Frontera, Facultad de Ciencias Agropecuarias y Forestales, Av. Francisco Salazar 01145, Temuco, Chile.

${ }^{2}$ Universidad Austral de Chile, Facultad de Ciencias Agrarias, Casilla 567, Valdivia, Chile. "Corresponding author (dalomar@uach.cl).

Received: 22 March 2010.

Accepted: 9 November 2010. with silage voluntary DM intake and content of digestible or metabolizable energy (Huhtanen et al., 2006).

Although the in vivo determination of digestibility is considered more accurate and therefore is employed as a reference method, it has also several drawbacks, such as cost, labour, extended time, availability of experimental animals and large amounts of feed needed (Huhtanen et al., 2006). Nonetheless, as Robinson et al. (2004) have pointed out, in vivo data cannot be disregarded as a reference method in the search for a reliably, accurate and precise digestibility predictive approach. Alternative laboratory methods have been devised to evaluate DMD, $\mathrm{OMD}$ and $\mathrm{D}$ value. Among them, the two stage in vitro technique with rumen fluid and pepsin hydrochloric acid (Tilley and Terry, 1963), but it requires rumen fistulated animals to obtain rumen fluid. Although methods using rumen fluid have widely and successfully been used to determine forage OMD, there are inherent problems in these applications such as high variability among fermentation runs and laboratories (Jones and Theodorou, 2000). Currently, near infrared reflectance spectroscopy 
(NIRS) allows fast, and multiple predictions, but it depends on the development of robust equations which requires of an important number of calibration samples covering a wide range of values and also dependable reference methods, as NIRS is a secondary prediction technique (Alomar and Fuchslocher, 1998; Rinne et al., 2006). The enzymatic method to estimate digestibility of forages mimics the ruminal degradation using cellulases from fungi such as Trichoderma viride and Aspergillus niger. Commercial enzymes are available which allow higher precision (Jones and Theodorou, 2000) and lower digestion time than the rumen fluid method. Variations in the cellulase method have been studied, mainly focusing on enzyme concentration and incubation time (Jones and Hayward, 1975; Aufrère, 1982; Dowman and Collins, 1982; Nousiainen et al., 2003a). The cellulase method seems to be a good alternative to predict DMD, OMD and D value of forages (Nousianen et al., 2003a), since it presents a good correlation with the rumen fluid method. Nonetheless, variability in methodology in relation to different types of ensiled forages deserves further study.

The objective of this work was to assess the effect of cellulase concentration, incubation time and type of final washing of the residues, on the DMD, OMD and $\mathrm{D}$ value of silages made from different pastures and in three phenological stages. Additionally, the relationship between results obtained with the in vitro methods based on cellulase and rumen fluid, was also evaluated.

\section{MATERIALS AND METHODS}

\section{Silages}

Silages made from four types of pastures were evaluated: a) a permanent pasture, comprising mainly Dactylis glomerata L., Lolium perenne L., Bromus catharticus Vahl var. catharticus, Trifolium repens L. and Holcus lanatus L.; b) Italian ryegrass ley (Lolium multiflorum Lam. cv. Tama); c) oats (Avena sativa L.) and d) a mixed pasture (Lolium perenne L.-T. repens). Each type of pasture or forage crop was harvested at three maturity stages of the dominant species: vegetative, early heading and soft dough grain and stored in duplicate in experimental stack silos sealed with polyethylene. Once the fermentation phase was completed, silos were opened and a composite sample per silo was collected, dried in oven at $60{ }^{\circ} \mathrm{C}$ for $48 \mathrm{~h}$, ground in a Wiley mill with a $1 \mathrm{~mm}$ screen (Arthur H. Thomas Co., Philadelphia, Pennsylvania, USA) and subsequently analyzed.

\section{In vitro digestibility procedure}

The two stage rumen fluid pepsin-hydrochloric acid technique (Tilley and Terry, 1963) was applied to obtain DMD, OMD and D value of silage samples. The enzymatic technique applied was the pepsin-cellulase method described by Jones and Hayward (1975) modified as follows. Three buffer cellulase solutions were prepared by dissolving $21.0 \mathrm{~g}$ citric acid and $28.3 \mathrm{~g}$ phosphate in distilled water, to prepare $2000 \mathrm{~mL}$ of solution with a $\mathrm{pH}$ 4.8. Cellulase from Trichoderma viride (Onozuka R-10, Yakult Pharmaceutical Ind., Japan; activity $11.7 \mathrm{U} \mathrm{g}^{-1}$ ) was added to give different enzyme concentrations $(0.75$, 1.0 and $6.25 \mathrm{~g} \mathrm{~L}^{-1}$ ) according to treatments.

The enzymatic digestion was carried out by adding $500 \mathrm{mg}$ of sample (oven dried at $60{ }^{\circ} \mathrm{C}$ and ground to pass a $1 \mathrm{~mm}$ screen) to $60 \mathrm{~mL}$ test-tubes with twist caps. A 50 $\mathrm{mL}$ solution of $2 \%$ pepsin (2000 FIP-U/g; Merck 7190, Darmstadt, Germany) with $0.1 \mathrm{~N}$ hydrochloric acid was added and the tubes were shaken. Thereafter, the tubes were incubated at $39^{\circ} \mathrm{C}$ for $24 \mathrm{~h}$, shaking every $6 \mathrm{~h}$. After incubation, samples were vacuum filtered (Whatman 41 filter paper) and the residues washed with hot distilled water. The residue in the paper was then transferred back to the respective test-tube by washing with a syringe with $50 \mathrm{~mL}$ of buffer cellulase solution prepared the day before and taking special care not to leave any visible particle of the residue in the paper. Each tube was shaken and incubated at $39^{\circ} \mathrm{C}$ for 24 or $48 \mathrm{~h}$, in accordance with the respective enzymatic treatment, shaking four times a day.

After the incubation was finished, the contents of the tubes were filtered through pre-weighed sintered glass crucibles (Schott Duran, porosity \# 1, Mainz, Germany) and washed with hot distilled water or acetone, according to treatment. Crucibles with residues were dried at $105^{\circ} \mathrm{C}$ for $12 \mathrm{~h}$ and weighed to obtain the content of indigestible dry matter. Thereafter, the crucibles were ashed at 500 ${ }^{\circ} \mathrm{C}$ for $5 \mathrm{~h}$ in an electric muffle furnace, cooled to room temperature and reweighed to obtain the indigestible organic matter. DMD, OMD and D value were estimated from these values.

\section{Enzymatic treatments evaluated}

Twelve combinations were evaluated for the pepsincellulase in vitro digestibility, consisting of two incubation times $(24$ or $48 \mathrm{~h})$, three cellulase concentrations $(0.75$; 1.0 and $6.25 \mathrm{~g} \mathrm{~L}^{-1}$ buffer) and two final washing types (distilled water or acetone).

\section{Determinations}

Rumen fluid and enzymatic in vitro digestibility values were calculated from the following relationships:

$$
\begin{aligned}
& \mathrm{DMD}=(\mathrm{DMi}-\mathrm{DMf}) / \mathrm{DMi} \\
& \mathrm{OMD}=(\mathrm{OMi}-\mathrm{OMf}) / \mathrm{OMi} \\
& \mathrm{D} \text { value }=(\mathrm{OMi}-\mathrm{OMf}) / \mathrm{DMi}
\end{aligned}
$$

where DMi: Initial amount $(\mathrm{g})$ of dry matter incubated, DMf: final amount or indigestible residue $(\mathrm{g})$ of dry matter after incubation stages, OMi: initial amount $(\mathrm{g})$ of 
organic matter incubated, OMf: final amount (indigestible residue) of organic matter after incubation stages $(\mathrm{g})$.

\section{Chemical analysis}

Silages were analyzed by AOAC (1996) methods for DM (method 984.13), total ash (method 942.05), total N (micro Kjeldahl, method 984.13), crude fibre (method 978.10) and acid detergent fibre (method 973.18). Silage $\mathrm{pH}$ was obtained by potentiometric reading of the extract. Ammonia $\mathrm{N}$ was determined by titration on the Kjeldahl distillate (Bateman, 1970). Gross energy was obtained with a bomb calorimeter (Parr adiabatic calorimeter; Parr Instruments, Moline, Illinois, USA).

The Tilley and Terry (1963) method was employed to obtain D value, which in turn was employed to estimate metabolizable energy (ME) according to a regression on in vivo values developed previously in our laboratory (Garrido and Mann, 1981).

\section{Statistical analysis and experimental design}

A preliminary ANOVA with a factorial design was applied to estimate the specific effects of enzyme concentration, incubation time and final washing on in vitro DMD, OMD and $\mathrm{D}$ value. If significant effects $(\mathrm{P}<0.05)$ were detected, the Tukey multiple comparison test was performed. In order to evaluate interactions among the above factors and also type of silage and maturity stage, a final analysis was performed including these factors. In some cases it took more than two replicates, so we used an unbalanced model. The corresponding mathematical model in the final analysis was as follows:

$\mathrm{Y}_{\mathrm{ijklmn}}=\mu+\alpha_{\mathrm{i}}+\beta_{\mathrm{j}}+\alpha \beta_{\mathrm{ij}}+\delta_{\mathrm{k}}+\beta \delta_{\mathrm{jk}}+\alpha \delta_{\mathrm{ik}}+\alpha \beta \delta_{\mathrm{ijk}}+x_{1}$ $+\beta \delta x_{\mathrm{jkl}}+\sigma_{\mathrm{m}}+\alpha \sigma_{\mathrm{im}}+\beta \sigma_{\mathrm{jm}}+\beta \delta \sigma_{\mathrm{jkm}}+\beta x \sigma_{\mathrm{jlm}}+\beta \delta x \sigma_{\mathrm{jklm}}$ $+\varepsilon_{\mathrm{jjk} \mathrm{mn}}$

where $Y_{\mathrm{ijklmn}}=$ observation; $\mu$ = overall mean; $\alpha_{\mathrm{i}}=$ fixed effect of silage type; $\beta_{\mathrm{j}}=$ fixed effect of maturity stage; $\delta_{\mathrm{k}}=$ random effect of incubation time; $x_{1}=$ random effect of washing type; $\sigma_{\mathrm{m}}=$ random effect of cellulase concentration; $\varepsilon_{\mathrm{jjklmn}}=$ residual error term that was assumed to be distributed normally; $\alpha \beta_{\mathrm{ij}}, \beta \delta_{\mathrm{jk}}, \alpha \delta_{\mathrm{ik}}$, $\alpha \beta \delta_{\mathrm{ijk}}, \beta \delta x_{\mathrm{jk} l}, \alpha \sigma_{\mathrm{im}}, \beta \sigma_{\mathrm{jm}}, \beta \delta \sigma_{\mathrm{jkm}}, \beta \varkappa \sigma_{\mathrm{jlm}}$ and $\beta \delta x \sigma_{\mathrm{jklm}}=$ effects of interactions.

Simple regression analysis was employed to relate DMD, OMD and D value results obtained with rumen fluid (dependent variable) and the same determinations obtained with the enzymatic technique (independent variable). Resulting equations were ranked according to the highest $\mathrm{R}^{2}$ and lowest root mean squared error (RMSE) (Steel and Torrie, 1988; Cody and Smith, 1991) in order to select the best enzymatic method. Statistical analysis was performed with the JMP statistical software (SAS Institute, 2009).

\section{RESULTS}

\section{Composition of silages}

Chemical composition of silages, gross and metabolizable energy content and in vitro (rumen fluid) digestibility of silages are presented in Table 1.

As expected, nutritional components change for each pasture as maturity stage increases. Furthermore, the highest ammonia- $\mathrm{N}$ content was observed in the permanent pasture and oat silages in early vegetative stage, which is indicative of extensive fermentation process and protein degradation in the ensiled material.

\section{Effects of enzymatic treatments}

Cellulase concentration, incubation time and washing type showed significant effects $(\mathrm{P}<0.05)$ on enzymatic $\mathrm{DMD}, \mathrm{OMD}$ and $\mathrm{D}$ value (Table 2).

The increase in enzyme concentration, incubation time from 24 to $48 \mathrm{~h}$ and washing with acetone instead of hot distilled water resulted in a higher $(\mathrm{P}<0.05)$ DMD, OMD and $\mathrm{D}$ value. A longer incubation time would facilitate the degrading effect of the enzymes on the cell walls, particularly in forages harvested in a later phenological stage. The use of acetone resulted in higher $(\mathrm{P}<0.05)$ digestibility values (DM and $\mathrm{OM}$ ) compared to washing with hot distilled water.

From the n-way ANOVA, no interactions were apparent $(\mathrm{P}>0.05)$ among enzyme concentration, incubation time and washing type for any enzymatic determination. They were evident also for other factors (silage type, maturity stage) albeit not consistent among them or when considering all digestibility variables (Table 3 ).

Strong interactions were found between maturity stage and enzyme concentration for DMD ( $\mathrm{P}=0.0011)$, OMD $(\mathrm{P}=0.0006)$ and $\mathrm{D}$ value $(\mathrm{P}=0.0001)$ suggesting that as plants mature, a high concentration of cellulase could be required to degrade secondary cell walls. Consequently, it is not surprising that a significant interaction was found $(\mathrm{P}=0.0001)$ among the factors type of ensiled forage, maturity stage and incubation time for $\mathrm{D}$ value (Table 3 ). The interaction type of silage $\mathrm{x}$ cellulase concentration was relevant only for $\mathrm{D}$ value $(\mathrm{P}=0.0104)$.

\section{Regression equations with rumen fluid results}

Regression equations of the DMD obtained with rumen fluid (y) over that obtained with cellulases (x), for the 12 treatments evaluated, are shown in Table 4. Coefficients of determination $\left(\mathrm{R}^{2}\right)$ and the RMSE are also included. The 12 treatments result from three enzyme concentrations, two incubation times and two washing methods. The best combination, explaining the highest proportion of the variance $(0.86)$ resulted from Treatment 12 , that is, the combination of the highest cellulase concentration 
Table 1. Chemical composition, dry matter digestibility and energy content (gross and metabolizable) of the silages in any phenological stage (DM basis, except pH).

Phenological stage

\section{Silage \\ Permanent pasture: \\ DM, g kg $^{-1}$}

Chemical composition, $\mathrm{g} \mathrm{kg}^{-1} \mathrm{DM}$

$$
\mathrm{CP}
$$

$\mathrm{CF}$

NDF

ADF

Ash

$\mathrm{pH}$

Ammonium $\mathrm{N}, \mathrm{g} \mathrm{kg}^{-1} \mathrm{~N}$

GE, $\mathrm{Mj} \mathrm{kg}{ }^{-1} \mathrm{DM}$

DMD ruminal fluid, $\mathrm{g} \mathrm{kg}^{-1}$

ME ruminal fluid, $\mathrm{Mj} \mathrm{kg}^{-1} \mathrm{DM}$

OMD ruminal fluid, $\mathrm{g} \mathrm{kg}^{-1}$

\section{Italian ryegrass:}

DM, $\mathrm{g} \mathrm{kg}^{-1}$

Chemical composition, $\mathrm{g} \mathrm{kg}^{-1} \mathrm{DM}$

CP

$\mathrm{CF}$

$\mathrm{NDF}$

ADF

Ash

$\mathrm{pH}$

Ammonium $\mathrm{N}, \mathrm{g} \mathrm{kg}^{-1} \mathrm{~N}$

GE, $\mathrm{Mj} \mathrm{kg}{ }^{-1} \mathrm{DM}$

DMD ruminal fluid, $\mathrm{g} \mathrm{kg}^{-1}$

ME ruminal fluid, $\mathrm{Mj} \mathrm{kg}^{-1} \mathrm{DM}$

OMD ruminal fluid, $\mathrm{g} \mathrm{kg}^{-1}$

\section{Mixed pasture:}

DM, $\mathrm{g} \mathrm{kg}^{-1}$

Chemical composition, $\mathrm{g} \mathrm{kg}^{-1} \mathrm{DM}$

$\mathrm{CP}$

$\mathrm{NDF}$

NDF

ADF

Ash

$\mathrm{pH}$

Ammonium $\mathrm{N}, \mathrm{g} \mathrm{kg}^{-1} \mathrm{~N}$

GE, $\mathrm{Mj} \mathrm{kg}{ }^{-1} \mathrm{DM}$

DMD ruminal fluid, $\mathrm{g} \mathrm{kg}^{-1}$

$\mathrm{ME}$ ruminal fluid, $\mathrm{Mj} \mathrm{kg}^{-1} \mathrm{DM}$

OMD ruminal fluid, $\mathrm{g} \mathrm{kg}^{-1}$

$$
164 \pm 1.0
$$

$146 \pm 1.2$

$325 \pm 3.0$

$621 \pm 3.1$

$375 \pm 1.3$

$99 \pm 0.9$

$4.82 \pm 0.05$

$196 \pm 2.6$

$19.7 \pm 0.17$

$719 \pm 2.7$

$9.96 \pm 0.04$

$715 \pm 1.5$

$167 \pm 3.2$

$120 \pm 2.7$

$348 \pm 11$

$610 \pm 27$

$411 \pm 12$

$90 \pm 3.4$

$4.03 \pm 0.20$

$97 \pm 9.9$

$18.7 \pm 0.25$

$749 \pm 1.6$

$10.5 \pm 0.04$

$752 \pm 00$

$183 \pm 26.6$

$174 \pm 5.7$

$277 \pm 3.0$

$499 \pm 9.2$

$318 \pm 7.3$

$103 \pm 0.9$

$3.81 \pm 0.04$

$102 \pm 0.4$

$19.4 \pm 0.04$

$818 \pm 8.1$

$11.3 \pm 0.04$

$827 \pm 4.0$
$211 \pm 4.6$

$112 \pm 9.0$

$342 \pm 24.1$

$635 \pm 28.5$

$396 \pm 22.2$

$83 \pm 2.8$

$4.23 \pm 0.34$

$112 \pm 9.4$

$19.1 \pm 0.25$

$689 \pm 7.4$

$9.79 \pm 0.13$

$690 \pm 15$

$216 \pm 2.7$

$$
89 \pm 1.1
$$

$317 \pm 4.7$

$578 \pm 13$

$375 \pm 5.3$

$88 \pm 4.0$

$3.69 \pm 0.06$

$85 \pm 6.5$

$19.0 \pm 0.17$

$724 \pm 2.6$

$10.2 \pm 0.00$

$726 \pm 3.1$

$219 \pm 1.6$

$133 \pm 4.2$

$302 \pm 6.4$

$567 \pm 13.8$

$367 \pm 2.6$

$89.4 \pm 1.9$

$3.84 \pm 0.05$

$81.8 \pm 21.3$

$18.9 \pm 0.04$

$736 \pm 41.7$

$10.3 \pm 0.50$

$740 \pm 39.4$
$272 \pm 10$

Dough grain

$300 \pm 3.0$

$$
\begin{gathered}
83 \pm 1.8 \\
350 \pm 14.0 \\
670 \pm 10 \\
424 \pm 8.1 \\
69 \pm 1.0 \\
4.14 \pm 0.065 \\
81 \pm 5.4 \\
18.5 \pm 0.23 \\
584 \pm 11.8 \\
8.49 \pm 0.21 \\
579 \pm 15.8
\end{gathered}
$$

$$
73 \pm 3.5
$$

$329 \pm 1.4$

$628 \pm 11$

$413 \pm 3.2$

$78 \pm 0.3$

$4.06 \pm 0.12$

$59 \pm 4.1$

$18.1 \pm 0.25$

$603 \pm 11$

$8.58 \pm 0.08$

$606 \pm 11$

$199 \pm 10.0$

$106 \pm 2.5$

$331 \pm 1.2$

$639 \pm 6.0$

$405 \pm 3.0$

$84.1 \pm 0.8$

$3.90 \pm 0.12$

$70.5 \pm 8.5$

$18.7 \pm 0.13$

$660 \pm 5.5$

$9.41 \pm 0.08$

$660 \pm 6.3$ 


\begin{tabular}{lccc}
\hline & \multicolumn{3}{c}{ Phenological stage } \\
\cline { 2 - 3 } Silage & Vegetative & Early heading & Dough grain \\
\hline Oats: & $166 \pm 8.6$ & $191 \pm 23.4$ & $253 \pm 7.0$ \\
DM, g kg-1 & & \\
Chemical composition, g kg-1 DM & $176 \pm 0.5$ & $113 \pm 3.9$ & $79.9 \pm 3.3$ \\
CP & $309 \pm 6.3$ & $348 \pm 9.1$ & $335 \pm 0.2$ \\
CF & $533 \pm 8.3$ & $606 \pm 0.95$ & $650 \pm 0.65$ \\
NDF & $365 \pm 6.2$ & $411 \pm 14.1$ & $409 \pm 7.3$ \\
ADF & $125 \pm 18.0$ & $89 \pm 3.6$ & $68 \pm 5.4$ \\
Ash & $4.29 \pm 0.21$ & $3.97 \pm 0.05$ & $3.96 \pm 0.02$ \\
pH & $132 \pm 26.0$ & $110 \pm 12.2$ & $104 \pm 10.8$ \\
Ammonium N, g kg-1 N & $18.9 \pm 0.33$ & $18.7 \pm 0.08$ & $18.7 \pm 0.13$ \\
GE, Mj kg-1 DM & $800 \pm 14.6$ & $759 \pm 10.1$ & $565 \pm 21.5$ \\
DMD ruminal fluid, $\mathrm{g} \mathrm{kg}^{-1}$ & $10.9 \pm 0.29$ & $10.6 \pm 0.25$ & $8.24 \pm 0.25$ \\
ME ruminal fluid, $\mathrm{Mj} \mathrm{kg}^{-1} \mathrm{DM}$ & $806 \pm 17.2$ & $707 \pm 35.1$ & $558 \pm 24.1$ \\
OMD ruminal fluid, $\mathrm{g} \mathrm{kg}^{-1}$ & & & \\
\hline
\end{tabular}

DM: dry matter; $\mathrm{CP}$ : crude protein $(\mathrm{N} \times 6.25)$; $\mathrm{CF}$ : crude fibre; NDF: neutral detergent fibre; ADF: acid detergent fibre; GE: gross energy; ME: metabolizable energy; OMD: organic matter digestibility.

(6.25 $\left.\mathrm{g} \mathrm{L}^{-1}\right)$, the longest incubation time $(48 \mathrm{~h})$ and final washing with acetone. This treatment also showed a smaller RMSE $(2.78 \%)$. The rest of the treatments employing $48 \mathrm{~h}$ of incubation explained over 0.82 of the variance. On average, treatments with $48 \mathrm{~h}$ of incubation explained in relative terms $c a .8 \%$ more of the variance in DMD, compared to $24 \mathrm{~h}$ incubation time. Of those treatments with $24 \mathrm{~h}$ incubation time, only Treatment 3 presented results close to the above mentioned, explaining 0.84 of the variance of in vitro DMD.
Relationships between determinations obtained with rumen fluid and the average results obtained with the cellulase treatments for DMD, OMD and D value, are presented in Figure 1.

The higher digestibility values correspond to silages made from oats, Italian ryegrass and mixed pasture, harvested in vegetative stage. Silages from permanent pasture in vegetative stage resulted in intermediate in vitro digestibility values, whereas those silages with a more mature stage showed lower values. These results

Table 2. Effect of cellulase concentration, incubation time and type of washing in D value, DMD and OMD of the silages.

\begin{tabular}{lccc}
\hline & D value & DMD & OMD \\
\cline { 2 - 4 } & & $\mathrm{g} \mathrm{kg}^{-1}$ & \\
\cline { 2 - 3 } Cellulase concentration, $\mathrm{g} \mathrm{L}^{-1}$ & $448 \mathrm{a}$ & $511 \mathrm{a}$ & $485 \mathrm{a}$ \\
6.25 & $411 \mathrm{~b}$ & $473 \mathrm{~b}$ & $445 \mathrm{c}$ \\
1.00 & $401 \mathrm{c}$ & $465 \mathrm{c}$ & $434 \mathrm{c}$ \\
0.75 & & & \\
Incubation time, $\mathrm{h}$ & & & $462 \mathrm{a}$ \\
$\quad 48$ & $426 \mathrm{a}$ & $490 \mathrm{a}$ & $448 \mathrm{~b}$ \\
24 & $413 \mathrm{~b}$ & $477 \mathrm{~b}$ & \\
Type of washing & & & $462 \mathrm{a}$ \\
$\quad$ Acetone & $427 \mathrm{a}$ & $489 \mathrm{a}$ & $447 \mathrm{~b}$ \\
$\quad$ Water & $413 \mathrm{~b}$ & $477 \mathrm{~b}$ & \\
\hline
\end{tabular}

Different letters between levels of each factor and for each variable indicate significant statistical differences $(\mathrm{P}<0.05)$. OMD: organic matter digestibility; DMD: dry matter digestibility. 
Table 3. Probability of effects of the studied factors and their interactions in the factor model analysis of variance for the dependent variables D value, DMD, and OMD.

\begin{tabular}{|c|c|c|c|}
\hline Source of variation & $\underset{P>\mathbf{F}}{\text { D value }}$ & $\begin{array}{l}\text { DMD } \\
P>\text { F }\end{array}$ & $\begin{array}{l}\text { OMD } \\
P>\text { F }\end{array}$ \\
\hline S & 0.0001 & 0.0001 & ns \\
\hline $\mathrm{PH}$ & 0.0001 & 0.0001 & 0.0066 \\
\hline $\mathrm{S} * \mathrm{PH}$ & 0.0001 & 0.0001 & ns \\
\hline $\mathrm{T}$ & 0.0001 & 0.0001 & ns \\
\hline $\mathrm{PH} * \mathrm{~T}$ & ns & ns & 0.0070 \\
\hline $\mathrm{S} * \mathrm{~T}$ & 0.0053 & 0.0053 & ns \\
\hline $\mathrm{S} * \mathrm{PH} * \mathrm{~T}$ & 0.0001 & ns & ns \\
\hline $\mathrm{W}$ & 0.0001 & 0.0001 & ns \\
\hline $\mathrm{PH} * \mathrm{~T} * \mathrm{~W}$ & ns & ns & 0.0069 \\
\hline $\mathrm{C}$ & 0.0001 & 0.0001 & ns \\
\hline $\mathrm{S} * \mathrm{C}$ & 0.0104 & ns & ns \\
\hline $\mathrm{PH} * \mathrm{C}$ & 0.0001 & 0.0011 & 0.0006 \\
\hline $\mathrm{PH} * \mathrm{~T} * \mathrm{C}$ & 0.0476 & ns & 0.0006 \\
\hline $\mathrm{PH} * \mathrm{~W} * \mathrm{C}$ & ns & ns & 0.0006 \\
\hline $\mathrm{PH} * \mathrm{~T} * \mathrm{~W} * \mathrm{C}$ & ns & ns & 0.0006 \\
\hline
\end{tabular}

OMD: organic matter digestibility; DMD: dry matter digestibility; S: silage type; PH: phenological stage; T: incubation time; W: wash (water or acetone); C: cellulase concentration; ns: non significant $(\mathrm{P}>0.05)$.

Table 4. Regression equations, coefficients of determination and estimation errors between dry matter digestibility (DMD, $\%$ ) with rumen fluid (y) and DMD obtained with cellulase (x) in the different treatments.

\begin{tabular}{lccc}
\hline Treatments & \multicolumn{1}{c}{ Equation } & $\mathbf{R}^{\mathbf{2}}$ & $\begin{array}{c}\text { RMSE } \\
(\boldsymbol{\%})\end{array}$ \\
\hline $24 \mathrm{~h}$, water, $0.75 \mathrm{~g} \mathrm{~L}^{-1}$ & $\mathrm{y}=0.95 \mathrm{x}+24.80$ & 0.765 & 3.45 \\
$24 \mathrm{~h}$, water, $1.0 \mathrm{~g} \mathrm{~L}^{-1}$ & $\mathrm{y}=0.94 \mathrm{x}+24.04$ & 0.759 & 3.61 \\
$24 \mathrm{~h}$, water, $6.25 \mathrm{~g} \mathrm{~L}^{-1}$ & $\mathrm{y}=0.87 \mathrm{x}+24.21$ & 0.843 & 2.92 \\
$24 \mathrm{~h}$, acetone, $0.75 \mathrm{~g} \mathrm{~L}^{-1}$ & $\mathrm{y}=0.89 \mathrm{x}+26.00$ & 0.776 & 3.48 \\
$24 \mathrm{~h}$, acetone, $1.0 \mathrm{~g} \mathrm{~L}^{-1}$ & $\mathrm{y}=0.76 \mathrm{x}+32.12$ & 0.614 & 4.58 \\
$24 \mathrm{~h}$, acetone, $6.25 \mathrm{~g} \mathrm{~L}^{-1}$ & $\mathrm{y}=0.84 \mathrm{x}+24.69$ & 0.813 & 3.19 \\
$48 \mathrm{~h}$, water, $0.75 \mathrm{~g} \mathrm{~L}^{-1}$ & $\mathrm{y}=0.92 \mathrm{x}+24.70$ & 0.784 & 3.43 \\
$48 \mathrm{~h}$, water, $1.0 \mathrm{~g} \mathrm{~L}^{-1}$ & $\mathrm{y}=0.93 \mathrm{x}+23.71$ & 0.823 & 3.07 \\
$48 \mathrm{~h}$, water, $6.25 \mathrm{~g} \mathrm{~L}^{-1}$ & $\mathrm{y}=0.93 \mathrm{x}+20.84$ & 0.834 & 3.00 \\
$48 \mathrm{~h}$, acetone, $0.75 \mathrm{~g} \mathrm{~L}^{-1}$ & $\mathrm{y}=0.95 \mathrm{x}+21.86$ & 0.826 & 3.07 \\
$48 \mathrm{~h}$, acetone, $1.0 \mathrm{~g} \mathrm{~L}^{-1}$ & $\mathrm{y}=0.93 \mathrm{x}+22.11$ & 0.837 & 2.97 \\
$48 \mathrm{~h}$, acetone, $6.25 \mathrm{~g} \mathrm{~L}^{-1}$ & $\mathrm{y}=0.87 \mathrm{x}+21.42$ & 0.858 & 2.78 \\
\hline
\end{tabular}

$\mathrm{R}^{2}$ = adjusted coefficient of determination; RMSE: root mean squared error.

are consistent with the interaction among type of silage, phenological stage and cellulase concentration, found for $\mathrm{D}$ value $(\mathrm{P}=0.0476)$ in the factorial model (Table 3). A higher dispersion of the data is seen for the silages of lower digestibility values, particularly those from permanent pasture, which in turn, at these lower values tend to be underestimated by the cellulase technique.
This is probably the result of an insufficient enzyme concentration in some of the treatments, especially when applied to plant material harvested in a mature stage. The floristic diversity of the permanent pasture and the fact that some species are more lignified than others at a later phenological stage, can also contribute to the higher variability mentioned above. 

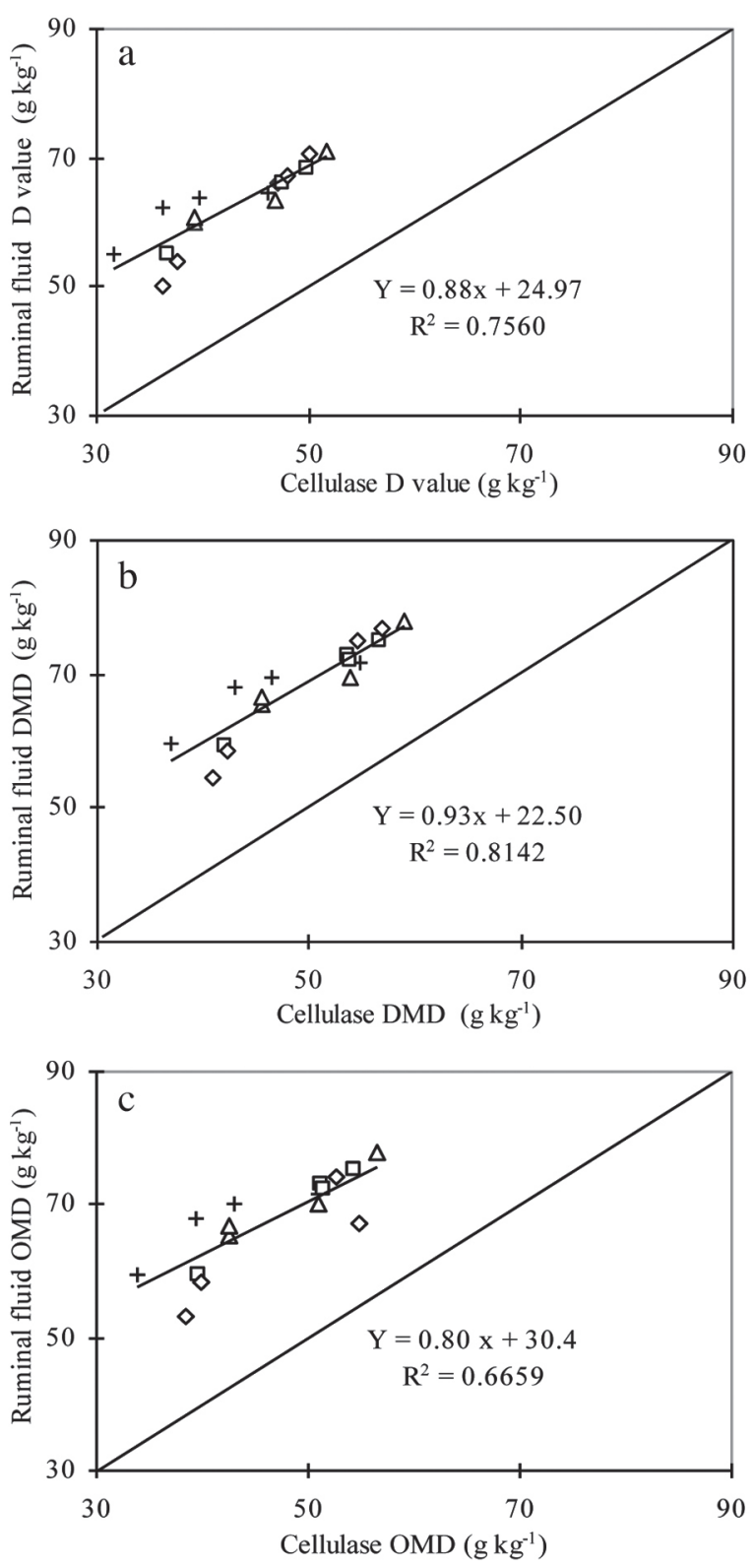

Figure 1. Relationship between values obtained by the cellulase and rumen fluid techniques, for $a: D$ value, $b$ : dry matter digestibility (DMD) and c: organic matter digestibility (OMD), of silages made from mixed pasture $(\Delta)$, permanent pasture $(+)$, Italian ryegrass $(\square)$, and oats $(\diamond)$.

\section{DISCUSSION}

Higher digestibility values with a longer incubation time are expected as a result of a more extensive exposure of the structural components of the cell walls to enzyme degradation. This is especially the case for silages of plant material harvested at a more mature stage. A number of works dealing with enzymatic digestibility has been published, but variations in laboratory procedures complicate the interpretation of results, making difficult to draw general conclusions and standardization of methods, particularly when different types of forages are involved (Rinne et al., 2006). Jones and Hayward (1975) applied $0.1 \mathrm{~N} \mathrm{HCl}$ in the first stage of digestion and $48 \mathrm{~h}$ for incubation with cellulases. Nousiainen et al. (2003a) incubated for $48 \mathrm{~h}$, which resulted in a relationship between OM solubility and in vivo OMD with a slope of 0.87 , probably as a result of the longer exposure time. Aufrère (1982) utilized $0.1 \mathrm{~N} \mathrm{HCl}$ and $24 \mathrm{~h}$ for the first incubation phase. Dowman and Collins (1982) based their methodology on the work of Jones and Hayward (1975), but with an incubation time of $24 \mathrm{~h}$. Roughan and Holland (1977) found a high correlation between cellulase solubility of DM and in vivo DMD, but they incubated for $48 \mathrm{~h}$ the cell walls remaining after neutral detergent extraction.

According to the results obtained, it could be assumed that the effect of enzymatic concentration is not independent of the fixed effects of plant material or stage at harvest, which has also been put forward by Jones and Hayward (1975). In the same way, De Boever et al. (1996) analyzed 64 different silages and found that the in vitro OMD values obtained with cellulase incubation presented differences in the correspondence to the regression equation of in vivo OMD, according to the stage of the pasture at harvest. They proposed that the amount of cellulase employed $\left(1.33 \mathrm{mg} \mathrm{mg}^{-1}\right.$ forage) could have been insufficient for the analysis of high fibre silages. According to the present work, a higher cellulase concentration would bring about a more extensive degradation of the cell wall structures, which is coincident with the report of Jones and Hayward (1975), who employed the same enzyme concentration. On the other hand, Aufrère (1982) found that although digestibility increased when cellulase concentration was changed from 0.5 to $1.0 \mathrm{~g} \mathrm{~L}^{-1}$, it tended to stabilize thereafter. Therefore, higher concentrations would be worthless, which seems not to be the case in the present study.

With respect to the type of washing, it is important to consider that chlorophyll is insoluble in water and, therefore, can be extracted with an organic solvent (Ihl et al., 2003) such as acetone, alcohol, ether or bencene. Washing with acetone should allow a complete extraction of chlorophyll and thus a higher D value and closer to the in vivo values.

An effect of the season and phenology of the plant material at harvest on the $\mathrm{D}$ value estimated with cellulases has been established (Givens et al., 1993a). This effect results from a different association between lignin and structural polysaccharides in the cell walls, 
when comparing forages harvested in autumn with those harvested in winter. The fact that the enzymatic solutions degrade the cell walls in a different fashion or to a different extent depending on the season of harvest, could justify the use of different prediction equations for each harvest season. Considerable higher errors have been found when predicting OMD of silages made from primary growth, together with those made from regrowths, instead of using separate equations (Nousiainen et al., 2003b). Givens et al. (1993a) point out that in the last cuts of the growing season the heterogeneity increases, which would lead to a poorer adjustment of the regression equations to predict $\mathrm{D}$ value and ME content. Kuoppala et al. (2008) analyzing regrowths in a mixed pasture of Phleum pratense $\mathrm{L}$. and Festuca pratensis Huds., report that although the increment on NDF is marginal compared to the primary growth, the corresponding increment in indigestible NDF is substantial, showing that not only the amount, but the quality of the cell walls is relevant. The above is consistent with the fact that the different performance of the cellulase method according to forage quality results in a higher standard deviation among silages (De Boever et al., 1996). Therefore, higher quality forages would require a lower enzyme concentration than forage harvested of late regrowths. As proposed by Givens et al. (1993b) a limiting factor of some predictive models developed from cellulases is that they are applied to forage samples which are different from those used to develop the equation. Nousiainen et al. (2003a) affirm that the higher precision found in their study of the in vitro method to predict $\mathrm{OMD}$ and $\mathrm{D}$ value could be explained by a higher uniformity of the ensiled material, compared to other trials.

\section{CONCLUSIONS}

In vitro digestibility traits are affected by enzyme concentration, length of the incubation and type of washing, which also interact with the type and phenological stage of ensiled forage. The best prediction of in vitro digestibility of the ensiled forages under study in this work was obtained with the highest enzyme concentration used $\left(6.25 \mathrm{~g} \mathrm{~L}^{-1}\right)$, independently of the incubation length (24 vs. $48 \mathrm{~h}$ ) and type of washing (acetone vs. water). The cellulase technique seems adequate to develop equations to predict the in vitro digestibility and related variables. However, more research is needed to develop local equations considering specific pasture types, harvest season and phenological stages and to corroborate such predictions with in vivo data.

\section{RESUMEN}

Digestibilidad mediante pepsina-celulasa de ensilajes de pradera: efectos del tipo de pradera, estado de madurez y variaciones en el método enzimático. La digestibilidad enzimática in vitro ha sido estudiada para predecir el valor energético de forrajes para rumiantes, aunque el tipo de forraje y los detalles metodológicos han afectado los resultados obtenidos. Este trabajo pretende evaluar los efectos de la concentración de celulasa $\left(0,75 ; 1,0\right.$ y $\left.6,25 \mathrm{~g} \mathrm{~L}^{-1}\right)$, tiempo de incubación (24 ó 48 h) y tipo de lavado final (agua o acetona) del residuo, sobre la digestibilidad in vitro de la materia seca (DMD), materia orgánica (OMD) y el contenido de materia orgánica digestible en la materia seca, o valor D (D value) de ensilajes hechos con tres estados de madurez, de diferentes praderas: a) pradera permanente (Dactylis glomerata, Lolium perenne, Bromus catharticus Vahl var. catharticus, Trifolium repens y Holcus lanatus); b) ballica Italiana (Lolium multiflorum Lam. cv. Tama); c) avena (Avena sativa L.); y d) pradera mixta (L.perenne-T. repens). Además, se ajustaron regresiones entre resultados con celulasas y digestibilidad in vitro con licor ruminal. Un incremento en la concentración de enzima, mayor tiempo de incubación y lavado con acetona incrementaron $(\mathrm{P}<$ $0,05)$ la DMD, OMD y valor D. Se detectó interacción $(\mathrm{P}<0,001)$ entre tipo de forraje, estado de madurez y tiempo de incubación y también $(\mathrm{P}<0,05)$ entre estado de madurez y concentración enzimática, para valor $\mathrm{D}, \mathrm{DMD}$ y OMD. El tipo de pradera y estado fenológico afectaron la capacidad del método enzimático para predecir la digestibilidad in vitro obtenida con licor ruminal. Por tanto, se debería desarrollar diferentes ecuaciones de predicción para cualquier combinación de los factores antes mencionados. El ajuste de esta metodología con valores in vivo ayudaría a mejorar las predicciones de valores de digestibilidad.

Palabras clave: incubación con celulasas, digestibilidad enzimática, digestibilidad in vitro.

\section{LITERATURE CITED}

Alomar, D., y R. Fuchslocher. 1998. Fundamentos de la espectroscopía de reflectancia en el infrarrojo cercano (NIRS) como método de análisis de forrajes. Agro Sur 26:88-104.

AOAC. 1996. Official methods of analysis. 15th ed. Association of Official Analytical Chemists, Washington, D.C., USA.

Aufrère, J. 1982. Etude de la prèvision de la digestibilitè des fourrages par une méthode enzymatique. Annales de Zootechnie 31:111-130. 
Bateman, J.V. 1970. Nutrición animal: Manual de métodos analíticos. 468 p. Centro Regional de Ayuda Técnica, México D.F.

Beever, D.E., and F.L. Mould. 2000. Forage evaluation for efficient ruminant livestock production. p. 15-42. In Givens, D.I., E. Owen, R.F.E. Axford, and H.M. Omed (eds.) Forage evaluation in ruminant nutrition. CABI Publishing, Wallingford, Oxon, UK.

Cody, R., and J. Smith. 1991. Applied statistics and the SAS programming language. $3^{\text {rd }}$ ed. 403 p. Elsevier Science Publishing Amsterdam, The Netherlands.

De Boever, J., B. Cottyn, D.L. De Brabander, J.M. Vanacker, and Ch. Boucque. 1996. Prediction of the feeding value of grass silages by chemical parameters, in vitro digestibility and near-infrared reflectance spectroscopy. Animal Feed Science and Technology 60:103-115.

Dowman, M., and F. Collins. 1982. The use of enzymes to predict the digestibility of animal feeds. Journal of the Science of Food and Agriculture 33:689-696.

Garrido, O., y E. Mann. 1981. Composición química, digestibilidad y valor energético de una pradera permanente de pastoreo a través del año. Tesis Ingeniero Agrónomo. Universidad Austral de Chile, Valdivia, Chile.

Givens, D., A. Moss, and A. Adamson. 1993a. Influence of growth stage and season on the energy value of fresh herbage. 2. Relationships between digestibility and metabolizable energy content and various laboratory measurements. Grass and Forage Science 48:175-180.

Givens, D., A. Moss, and A. Adamson. 1993b. Prediction of the digestibility and energy value of grass conserved in big bales. Animal Feed Science and Technology 41:297-312.

Huhtanen, P., J. Nousiainen, and M. Rinne. 2005. Prediction of composition and organic matter digestibility from herbage composition and pepsincellulase solubility. Agricultural and Food Science 14:154-165.

Huhtanen, P., J. Nousiainen, and M. Rinne. 2006. Recent developments in forage evaluation with special reference to practical applications. Agricultural and Food Science 15:293-323.

Ihl, M., L. Aravena, E. Scheuermann, E. Uquiche, and V. Bifani. 2003. Effects of immersion solutions on shelflife of minimally processed lettuce. LebensmittelWissenschaft und-Technologie 31:51-58.

Jones, D., and M. Hayward. 1975. The effect of pepsin pretreatment of herbage on the prediction of dry matter digestibility from solubility in fungal cellulase solutions. Journal of the Science of Food and Agriculture 26:711-718.
Jones, D., and M. Theodorou. 2000. Enzyme techniques for estimating digestibility. p. 155-173. In Givens, D., E. Owen, R. Axford, and H. Omed (eds.) Forage evaluation in ruminant nutrition. CABI Publishing, Wallingford, Oxon, UK.

Kuoppala, K., M. Rinne, J. Nousiainen, and P. Huhtanen. 2008. The effect of cutting time of grass silage in primary growth and regrowth and the interactions between silage quality and concentrate level on milk production of dairy cows. Livestock Science 116-171182.

Nousiainen, J., M. Rinne, M. Hellämäki, and P. Huhtanen. 2003a. Prediction of the digestibility of the primary growth of grass silages harvested at different stages of maturity from chemical composition and pepsincellulase solubility. Animal Feed Science and Technology 103-97-111.

Nousiainen, J., M. Rinne, M. Hellämäki, and P. Huhtanen. 2003b. Prediction of the digestibility of primary growth and regrowth grass silages from chemical composition, pepsin-cellulase solubility and indigestible cell wall content. Animal Feed Science and Technology 110:61-74.

Rinne, M., A. Olt, J. Nousiainen, A. Seppa, M. Tuori, C. Paul, M. Fraser, and P. Huhtanen. 2006. Prediction of legume silage digestibility from various laboratory methods. Grass and Forage Science 61:354-362.

Robinson, P.H., D.I. Givens, and G. Getachew. 2004. Evaluation of NRC, UC Davis and ADAS approaches to estimate the metabolizable energy values of feeds at maintenance energy intake from equations utilizing chemical assays and in vitro determinations. Animal Feed Science and Technology 114:75-90.

Roughan, P.G., and R. Holland. 1977. Predicting in vivo digestibilities of herbages by exhaustive enzymatic hydrolysis of cell walls. Journal of Science of Food and Agriculture 28:1057-1064.

SAS Institute. 2009. JMP 8 design of experiments. SAS Institute, Cary, North Carolina, USA.

Steel, R., y J. Torrie. 1988. Bioestadística: principios y procedimientos. $2^{\text {a }}$ ed. 622 p. McGraw-Hill, México.

Tilley, J., and R. Terry. 1963. A two stage technique for the in vitro digestion of forage crops. Journal of the British Grassland Society 18:104-111. 